\title{
Poverty Alleviation in the Aspect of Government Collaboration with NGOs
}

\author{
Phen Huang Thun ${ }^{1}$, Tran Duy Manh ${ }^{1}$ \\ ${ }^{1}$ Faculty of Social Sciences and Humanities, Ton Duc Thang University, Vietnam \\ Received: March 6, 2021 \\ Received in Revised: April 7, 2021 \\ Accepted: April 18, 2021
}

\begin{abstract}
This report addresses the government's and non-governmental organizations' roles in resolving poverty issues. Several of the government's positions in poverty alleviation are classified according to fiscal, health, academic, technical, and social factors. Collaboration between nongovernmental organizations and the government will result in community welfare. This is shown by the many empowerment initiatives undertaken by the private sector and government to solve the issue of poverty. For example, growing children's education by requiring them to attend school and increasing women's empowerment by promoting different aspects of education and empowerment, such as free schooling and others. Apart from the economic field, the government and non-governmental organizations offer training to allow citizens to be more innovative in their raw material production. Additionally, in the health field, it is important for NGOs to protect the community's health in order for them to live by delivering free medical care and so on.
\end{abstract}

Keywords: Poverty, Government, NGO

\section{Introduction}

Poverty has a relative definition; in industrialized countries, poor conditions are characterized as being jobless, while in developing countries, poor conditions imply that a person's basic needs, including clothes, food, and housing, are not met. Thus, the definition of poverty must be seen from a particular lens and background. Apart from civil society, policymakers in developing countries, referred to as NGOs, have done an excellent job of reducing the pressure on the government to assist citizens in escaping poverty. Meanwhile, in developed nations, the majority of poverty alleviation is done by the state, with no knowledge of the social institutions' help. As a result, the issue of suffering will never be overcome. Developed nations also play a part in assisting emerging countries in combating hardship through humanitarian relief programs (financial help) and development assistance (official development assistance). However, each assist has prerequisites, much like a coin has two sides. The first side is concerned with' money swapping hands,' while the second side is concerned with 'ideas changing minds.' All assistance cannot be provided for free; it must adhere to the donor country's requirements. The first side of the coin focuses on the 'budget, oversight, and openness' issues. While the second side stresses the difficulty in improving people's mindset to the point that they are no longer lazy, but would be imaginative in their movement to achieve anything useful. Although capital assistance is critical on both economic and social levels, it does not guarantee that it would result in a country's citizens becoming successful. It all comes down to the capacity to use and process assistance in order to create something useful and effective.

The aim of empowering the poor through promotional efforts is to empower the poor through partnering and synergizing with government agencies/organizations and non-governmental organizations to improve responsive programs in an attempt to raise visibility, educate, convince, and impact the poor in some potential places. independently. The coordination in 
question includes the involvement of regional officials at all levels. Lower-level leaders must be supported by top-level leadership in empowering and mobilizing village populations. Cooperation that includes both parties takes authority and the capacity to make choices, especially when it comes to budget allocation (Brinkerhoff, 2001). Poverty alleviation is a complex (meta) challenge that needs the appropriate policies to address distribution disparities, inadequate access, and the poor's capacity to participate in economic activities (Sovacool, 2012; Quinn \& Kumar, 2014; Levin \& Bigsten, 2000). The nation would prove incapable of resolving society's complicated issues on its own. In this case, the position of NGOs is critical in assisting the government in alleviating its burden / obligation to the society ( Warleigh, 2001 ; Warhurst, 2005; Waddell, 2017).). As a third player (third sector), NGOs will assist the government in resolving growth issues. The following are some of the poverty-related concerns that often exist in developed countries: child labour, illiteracy, poor working capital, low ability levels, debt slavery, high birth rates, and difficulties fulfilling essential needs (clothing, food, and shelter). erosion of farm land.

\section{The Concept of Cooperation between NGOs and the Government}

Networking, or networking, is a set of interrelated tasks that must be performed in a certain sequence in order to accomplish the mission. The tasks are carried out in a sequential order, beginning with the introduction of coaching and ending with the completion of other activities.

Cooperation is critical in the operation of a relationship or partnership (Das et al.,1998; Wei et al., 2012). This is because a relationship enables each institution's priorities to be quickly accomplished. For instance, the corresponding Foundation's work on neglected children greatly assists the Provincial Government in delivering resources to neglected children.

The process of transition and the actions required to achieve an economically stable state are a constant presence in people's lives (Ghisellini et al., 2016; Jackson, 2009). If we examine this fact closely, we can see that it comprises many fundamental components. When any of these fundamental components are reconstructed, a full figure describing this fact will emerge. The face of this fact is a multifaceted phase of transition toward a more harmonious partnership between needs and resources as a result of community capacity development, particularly in using opportunities and resources, forecasting obstacles, and resolving social issues as they occur, in order to establish more prosperous living conditions.

Of necessity, the Child Welfare Institution's efforts to empower abandoned children would be aided by the provision of services that address the issue of neglected children. The primary criterion for cooperation is that the society must be deeply ingrained, whereas the other side must be open and adaptable to ongoing changes. When an organization is remembered, valued, the advantages are felt, and it is used as a guide for collective action, it has a rooted essence. to be eligible to offer programs such as schooling, health care, government support for the vulnerable, and adoption services.

Capability refers to each party's capacity for resolving issues including abandoned children. In this situation, Foundation is critical in coping with lost infants, since the corresponding Foundation looks after them on a daily basis.

\section{Partnership Pattern}

Pseudo-Partnership A pseudo relationship is an arrangement involving two or more individuals that may not include them cooperating in a balanced manner. Mutualism, or mutualistic relationship, is an arrangement between two or more individuals that are mutually mindful of the critical implications of forming a partnership, which is to offer advantages and obtain additional benefits, in order to accomplish objectives more efficiently. Conjugation 
Relationships, also known as convergence and growth partnerships, are collaborations comprised of organizations, agents, associations, or entities that face difficulties doing business or meeting organizational objectives. This concept may be used to incorporate partnerships. Thus, the author employs the hypothesis of collaboration and partnership trends in her study since this theory will later be used to determine if the partnership method is effective in reducing the number of abandoned children.

As a result, the government must expand voluntary citizen involvement in order to assist in resolving the issue of abandoned infants (homeless). This is because community-based planning would be more centered on the issue at hand. It will be explanatory in nature in subsequent study, which will provide an examination of relationships between the government and social organizations. And the anticipated outcome of the research that will be conducted later this year will influence the government to further motivate the community in addressing child issues, as well as NGOs to work more closely with the government in order to foster a development-based government climate that benefits all populations.

\section{The Role of Non-Governmental Organizations in Poverty Alleviation}

Among the functions of NGOs in addressing poverty issues is creativity, which refers to the involvement of NGOs in developing projects that address the primary needs of the vulnerable. In this case, an NGO's job is to generate developments through the architecture, programming, and execution of activities. For example, NGOs have pioneered non-formal primary education initiatives, organized campaigns across literacy support communities, organized joint viewing events in villages to promote a sense of community and cooperation, and organized computer training activities to educate the poor.

As an autonomous body, NGOs are unaffected by government program interventions on both a state and national level. Apart from that, NGO operations are not heavily affected by the demands of local government-generated public policy, which means that NGOs retain the right to define the vision and task towards which they serve.

Typically, NGOs employ professionals in specific areas. Occasionally, their experience rivals that of government staff. Their experience is extremely beneficial in resolving society's real problems. Specialized abilities (specialization) are advantageous for developing unique services that increase the poor's quality of life, such as the NGO. The Grameen Phone Lady in Bangladesh.

In this situation, NGOs contribute to access through health care, informal schooling, collaboration to develop village group infrastructure, and provision of information technology. NGOs play a part in this situation by educating citizens about the possession of natural resources, such as food and security, as legitimate rights. NGOs will engage in this activity by providing instruction and collaborating with other non-governmental organizations to further the common good. In this situation, NGOs are trusted to carry out the role of poverty alleviation because they are deemed to have the freedom to develop organizational management systems focused on the values of professionalism, expertise, accountability, dependability, openness, and continuity in promoting the poor's welfare. In this situation, NGOs are entrusted with the responsibility of providing judicial security for small citizens who are denied justice in the middle of a country's political existence.

\section{Government and NGOS Efforts in Alleviating Poverty}

NGOs play a critical position in poverty alleviation by advocating for the elimination of school fees, uniform fees, and other expenditures for vulnerable children in Kenya and Uganda. In India, an NGO named Pratham has also introduced a unique initiative in the form of tutoring 
programs and accelerated learning (accelerated classes) for vulnerable children in order to help them keep up with India's underdeveloped knowledge base. In India, an NGO named SEWA (Self Employed Women's Association) seeks to boost women's welfare by offering skills training that enables them to manufacture goods to market. It is hoped that the empowerment program would allow women in India to be self-sufficient and productive, free from the shackles of physical (decent life) and spiritual (good mentality) poverty. World Vision in Peru has a non-governmental organization named ADEW that works on educating women through technical training and outreach on the defense of women's rights. Large NGOs such as Oxfam International also have an initiative called the 'Global Social Movement' that seeks to alleviate hunger and social inequality on a global scale.

in resolving health issues, such as an NGO named Finca's hunger-free initiative in Uganda and Ghana. The International Relief Committee is a non-governmental organization that aims to reduce hunger by supplying nutritional supplements to the vulnerable in many developed countries. CARE, a non-governmental organization, counseled Ethiopians about the benefits of regulating birth rates and improving baby and child welfare.

Moving away from schooling and welfare, NGOs also contribute to neighborhood poverty alleviation through addressing economic issues. For eg, in Bangladesh, an NGO named Grameen and BRAC supported the poor with capital through microcredit, marketing access, and training. Additionally, an NGO in Nepal named FMMC assists local communities in establishing alternate sources of income. This is because many private businesses in Nepal prioritize the economic well-being of their investors over the economic well-being of their employees. In India's Maboobnagar district, an NGO named Krishna Bhima Samruddhi provides credit assistance to small farmers, especially for fertilizer and seed purchases, with the goal of avoiding monopolization by large farmers. Africare is a non-governmental organization whose aim is to provide development services for remote rural communities located in mountainous areas that are disconnected from modernization. The Africare NGO's mission is to educate the public about modern alternative plant sources that have a strong added benefit. For example, the group grows fruit plants adapted to mountainous conditions. Apart from the market, many NGOs concentrate on assisting the vulnerable in developed countries with technology transfer. One such non-governmental organization (NGO) (Consultative Group on International Agricultural Research) works to combat agricultural degradation by supplying local farmers with expertise in soil conservation through the use of agricultural technology. Apart from that, NGOs assist in resolving environmental issues, such as the Indian NGO Gram Vikas, which offers training in proper natural resource management, especially spring water supplies, for the benefit of the local community. Additionally, a Kenyan nongovernmental organization named Greenbelt is inviting grassroots local groups to reforest abandoned woods. There are many additional instances that demonstrate the critical function of NGOs in relieving the government's responsibility of alleviating development issues such as hunger.

\section{Conclusion}

Poverty alleviation is a multifaceted (meta) challenge that demands the appropriate policies to address distribution disparities, inadequate access, and the poor's capacity to participate in economic activities. The nation would prove incapable of resolving society's complicated issues on its own. In this case, the position of NGOs is critical in assisting the government in alleviating its burden / obligation to the society. The government and non-governmental organizations work together to eradicate poverty, primarily by networking, desire, confidence, teamwork, and power. Additionally, NGOs work on a variety of fields, including wellness, 
schooling, technology, and social issues. To mobilize the government and non-governmental organizations for the common good.

\section{References}

Brinkerhoff, D. W. (2001). Taking account of accountability: A conceptual overview and strategic options. Draft Report, US Agency for International Development, Center for Democracy and Governance, Implementing Policy Change Project, Phase, 2.

Das, T. K., \& Teng, B. S. (1998). Between trust and control: Developing confidence in partner cooperation in alliances. Academy of management review, 23(3), 491-512.

Ghisellini, P., Cialani, C., \& Ulgiati, S. (2016). A review on circular economy: the expected transition to a balanced interplay of environmental and economic systems. Journal of Cleaner production, 114, 11-32.

Jackson, T. (2009). Prosperity without growth?: The transition to a sustainable economy. Available $\quad$ From: https://research-repository.standrews.ac.uk/bitstream/handle/10023/2163/sdc-2009-pwg.pdf?seq

Levin, J., \& Bigsten, A. (2000). Growth, income distribution, and poverty: A review. rapport nr.: Working Papers in Economics, (32).

Quinn, S. C., \& Kumar, S. (2014). Health inequalities and infectious disease epidemics: a challenge for global health security. Biosecurity and bioterrorism: biodefense strategy, practice, and science, 12(5), 263-273.

Sovacool, B. K. (2012). The political economy of energy poverty: A review of key challenges. Energy for Sustainable Development, 16(3), 272-282.

Waddell, S. (2017). Societal learning and change: How governments, business and civil society are creating solutions to complex multi-stakeholder problems. Routledge.

Warhurst, A. (2005). Future roles of business in society: the expanding boundaries of corporate responsibility and a compelling case for partnership. Futures, 37(2-3), 151-168.

Warhurst, A. (2005). Future roles of business in society: the expanding boundaries of corporate responsibility and a compelling case for partnership. Futures, 37(2-3), 151-168.

Warleigh, A. (2001). 'Europeanizing'civil society: NGOs as agents of political socialization. JCMS: Journal of Common Market Studies, 39(4), 619-639.

Wei, H. L., Wong, C. W., \& Lai, K. H. (2012). Linking inter-organizational trust with logistics information integration and partner cooperation under environmental uncertainty. International Journal of Production Economics, 139(2), 642-653. 